\title{
New record of Nyctinomops aurispinosus with an update of its
} known distribution

\section{Nuevo registro de Nyctinomops aurispinosus con una actualización de su distribución conocida}

\author{
Gandhy Portugal-Zegarra ${ }^{1,2,4}$ * ${ }^{\text {, Marisel Flores-Quispe }}{ }^{1,3}$, Giüseppy Calizaya-Mamanil ${ }^{1,3}$, and Giovanni Aragón Alvarado ${ }^{1,4}$ \\ 'Programa de Conservación de Murciélagos de Perú (PCMP). Lima, Perú. E-mail: gandalpz182@gmail.com (GP-Z), fq.marisel@ \\ gmail.com (MF-Q), epiorama@gmail.com (GC-M), gioralva@gmail.com (GAA). \\ ${ }_{2}^{2}$ Mahuilque Spa, Servicios Generales Mahuilque Ingeniería Geomensura. Santo Domingo 1381, Santiago de Chile, Chile. \\ ${ }^{3}$ Consultoría \& Monitoreo Perú S. A. C. Servicio de Implementación del Plan de Gestión de Biodiversidad-Proyecto Quellaveco. \\ Cooperativa Banco del Sur Mz. B Lt. 2 Urb. Santo Domingo Quinta Estancia J. L. B. y R., Arequipa, Perú. \\ ${ }^{4}$ Universidad Nacional Jorge Basadre Grohmann, Facultad de Ciencias. Av. Miraflores s/n., Tacna, Perú. \\ *Corresponding author
}

Nyctinomops aurispinosus is one of four species of the genus Nyctinomops (Molossidae) and is considered monotypic. This insectivorous species has a wide but poorly known neotropical distribution. This study documents the first record of the species for the Sama Valley, Tacna department, Perú. In addition, a current distribution map of the species is presented together with facts concerning its dietary composition. The specimen was collected using mist nets during a local bat study and compared with $N$. aurispinosus individuals in the scientific collection of the Museo de Historia Natural Javier Prado, Universidad Nacional Mayor de San Marcos. The distribution map was made of published records and the diet of the specimen was analyzed by stereoscopy of the contents of its digestive tract. The collected specimen was identified as an adult male N. aurispinosus in reproductive condition. Analysis of the digestive tract contents showed that its diet was composed of lepidopterans. The current distribution map of the species consisted of a total of 78 published records. This new record for Tacna department expands the distribution of N. aurispinosus ca. $270 \mathrm{~km}$ to the south of Camaná, Arequipa department, becoming the southernmost record for the Pacific coast. The lepidopteran remains in the digestive tract show that its diet is similar to those reported for other molossids. This finding extends the known distribution of this species to the southwest of South America and increases to ten the number of bat species known from Tacna department. The proximity of this Peruvian record to Chilean territory and regional habitat continuity suggests the probable presence of $N$. aurispinosus in that country.

Keys words: Desert; diet; molossids; range; Tacna; valley.

Nyctinomops aurispinosus es una de las cuatro especies del género Nyctinomops (Molossidae), monotípica e insectívora de amplia distribución Neotropical, pero muy poco conocida. El presente estudio documenta el primer registro de la especie para el valle de Sama, departamento de Tacna, Perú, además se elabora el mapa de distribución actual de la especie y brinda aportes sobre la composición de su dieta. El ejemplar fue colectado en un estudio de quiropterofauna local utilizando redes niebla y comparado con individuos de N. aurispinosus de la colección científica del Museo de Historia Natural de la Universidad Nacional Mayor de San Marcos. El mapa de distribución se realizó mediante registros publicados y la dieta del ejemplar se analizó por estereoscopia del contenido de su tracto digestivo. El ejemplar colectado fue identificado como un individuo de $N$. aurispinosus, macho, adulto y en etapa reproductiva. El análisis del contenido del tracto digestivo reveló que su dieta estuvo compuesta de lepidópteros. La elaboración del mapa de distribución actual de la especie comprendió un total de 78 registros publicados. Este nuevo registro para el departamento de Tacna expande la distribución de N. aurispinosus en aproximadamente 270 km al sur de Camaná, departamento de Arequipa, convirtiéndose en el más austral para la costa del Pacífico. Las estructuras de lepidópteros en el contenido del tracto digestivo del ejemplar revelan que la dieta de la especie es similar a la reportada en otros molósidos. Este hallazgo incrementa la distribución conocida de esta especie hacia el suroeste de Sudamérica, además de elevar a diez el número de especies de murciélagos conocidas para el departamento de Tacna. Debido a la proximidad del registro y similitud de hábitats entre el sur del Perú y el norte de Chile se sugiere la presencia de N. aurispinosus en este último país.

Palabras clave: Desierto; dieta; molósidos; rango; Tacna; valle.

(C) 2020 Asociación Mexicana de Mastozoología, www.mastozoologiamexicana.org

The insectivorous bat family Molossidae has a pantropical distribution (Simmons 2005; Peracchi et al. 2011) and is represented by 11 genera and 50 species in the Neotropics (Solari and Martinez-Arias 2014; Medina et al. 2014; Loureiro et al. 2018; Moras et al. 2018), being 29 the species that have been reported for Perú (Pacheco et al. 2009; Gregorin and Chiquito 2010; Díaz 2011; Medina et al. 2012, 2014). In this family, the genus Nyctinomops Miller 1902 is distributed widely in the Western Hemisphere: from Canadá, United States, México, Belize, El Salvador, Cuba, Jamaica, Haití, Honduras, Nicaragua, Guatemala, Dominican Republic, Panamá, Guyana, French Guyana, Surinam, Colombia, Venezuela, Ecuador, Trinidad and Tobago, Brazil, Perú, Bolivia, Paraguay, to Argentina, and Uruguay (Silva-Taboada and Koopman 1964; McCarthy et al. 1987; McCarthy et al. 1993; Nowak 1994; Simmons 2005; Eger 2008; Owen and 
Girón 2012; Medina-Fitoria et al. 2015; Kraker-Castañeda et al. 2016; Soto-Centeno et al. 2017). The individuals documented in Canadá (British Columbia) and the United States (states of lowa and Kansas) are considered as vagrants or extralimital records (Milner et al. 1990). There are four species of Nyctinomops: N. laticaudatus (É. Geoffroy St.-Hilaire 1805), N. macrotis (Gray 1839), N. aurispinosus (T.R. Peale 1848), and N. femorosaccus (Merriam 1889).

Peale's free-tailed bat, $N$. aurispinosus was described as Dysopes aurispinosus, with a type locality south of Cape St. Roque, Estado do Río Grande do Norte, Brazil (Peale 1848). Later, Cassin (1858) used the name Molossus aurispinosus for the specimen described by Peale because of its similarity to M. rugosus d'Orbigny, 1837 (a synonym of Tadarida brasiliensis brasiliensis I. Geoffroy St. Hilaire 1824) but differing in the color of the fur. Moreover, this author questioned the use of the specific epithet "aurispinosus", which translated from the Latin means "thorny ear" (an external characteristic of $N$. aurispinosus) because of its resemblance to the translation "golden ear".

Afterwards, Miller (1902) described the genus Nyctinomops conformed by eight species, designating $N$. femorosaccus as type species. This author also argued that Nyctinomops members were intermediate in body size between the genera Promops and Tadarida, distinguished from Promops by narrowly separated premaxillaries anteriorly and from Tadarida by its possession of parallel upper incisors that are sometimes in contact with each other.

Shamel (1931) synonymized Nyctinomops with the genus Tadarida, but recognized two groups; the first with nine smallish species (the brasiliensis group) and the second with six larger species (the macrotis group), including Tadarida aurispinosa, T. europs, T. femorosacca, T. laticaudata, T. macrotis, and T. yucatanica. Later, T. europs and T. yucatanica were recognized as T. laticaudata europs (Jones and Álvarez 1962) and T. I. yucatanica (Silva-Taboada and Koopman 1964), respectively, leaving the macrotis group conformed by four species. Through a phenetic analysis of the family Molossidae, Freeman (1981) found similarities among these four species of the macrotis group, grouping them in the genus Nyctinomops with the names of their original descriptions ( $N$. aurispinosus, $N$. femorosaccus, $N$. laticaudatus and N. macrotis).

Nyctinomops aurispinosus is distributed in México, Honduras, Colombia, Venezuela, Brazil, Bolivia, and Perú from sea level to 3,115 m (Peale 1848; Sanborn 1941; Ortiz de la Puente 1951; Carter and Davis 1961; Ochoa 1984; lbáñez and Ochoa 1989; Espinal et al. 2016), being most frequently reported below 1,000 m (Jones and Arroyo-Cabrales 1990). In México, it is found in tropical deciduous forest and trees of the genus Cupresus, around rivers and thorny deciduous riparian forests (Gardner 1963; Jones and Álvarez 1964; Baker and Jones 1972; Wang et al. 2003), as well as in tropical vegetation, thorny bushes, cacti, oak, grasslands, and mesquites (Baker et al. 1967; Wilson 1985; López-González and García-Mendoza 2006). In Honduras, it was reported in pine- oak forests with pastures converted for livestock (Espinal et al. 2016); in Venezuela, in very humid pre-montane forest (Ochoa 1984); in Bolivia, it was reported in spiny trees along the edges of fresh water sources (Ibáñez and Ochoa 1989); in Brazil, it has been recorded in the Cerrado, Caatinga, and Atlantic Forest biomes (Taddei and Garutti 1981; Bredt 2003; Eger 2008; Bianconi et al. 2009; Tavares et al. 2010; Aguiar et al. 2012; Garbino 2016; Oliveira et al. 2019); whereas in Perú, $N$. aurispinosus is distributed in the Dry equatorial forest (characterized by flora of the families Capparaceae, Cassuarinaceae, Fabaceae, and Loranthaceae), Pacific coastal desert, and Subtropical puna (Ortiz de la Puente 1951; Sanborn 1951; Eger 2008; Velazco et al. 2013; Pari et al. 2015).

The holotype of $N$. aurispinosus is deposited in the Smithsonian National Museum of Natural History (USNM 3726 , collected by Peale on November $18^{\text {th }}, 1848$ ) and is an adult male preserved in alcohol with removed skull that was subsequently misplaced (Shamel 1931). From the registration of the holotype to today, the wide distribution of $N$. aurispinosus stands in contrast to the few specimens in scientific collections around the world; this relates to the fact that molossids represent about $11.7 \%$ of the bat specimens in museums, because their flight characteristics and echolocation make them difficult to capture by conventional methods (Ammerman et al. 2012).

Ortiz de la Puente (1951) reported the first Peruvian record of $N$. aurispinosus from Lima department (Museo de Historia Natural de la Universidad Nacional Mayor de San Marcos - MUSM 235, 6051). Sanborn (1941) and Carter and Davis (1961) referred a specimen (Field Museum of Natural History - FMNH 68561) collected in Marcapata, Huajyumbe in Cuzco department to this species. Later, Eger (2008) and Dolman and Ammerman (2015) reported N. aurispinosus (Louisiana State University Museum of Zoology, Baton Rouge, Louisiana, USA - LSUMZ 25011, 25012, 25013, 25014, 25021, 25022, 25029) $12 \mathrm{~km}$ from Olmos in Lambayeque department. Velazco et al. (2013) reported two specimens (American Museum of Natural History - AMNH 278527 and Colección de Mastozoología, Centro de Ecología y Biodiversidad, Lima, Perú - CEBIOMAS 228) from La Brea, Talara in Piura department, and Pari et al. (2015) reported a specimen (without catalogue information) collected in Camaná, Arequipa department. Recent research has documented an important diversity of insectivorous bats in the south of Perú (molossids and vespertilionids; Medina et al. 2014; Flores-Quispe et al. 2015; Málaga et al. 2020); however, the difficulty of catching individuals has hampered learning about their natural history.

In this study, we present the first record of N. aurispinosus for Tacna department in the extreme south of Perú, which extends its known geographical distribution, and consider this in the context of the currently known distribution of the species. Additionally, we offer the first contributions about the diet of these bats through microscopic examination of its digestive tract contents. 
The capture location ( $-17^{\circ} 49^{\prime} 58.23^{\prime \prime} \mathrm{S},-70^{\circ} 30^{\prime} 41.07^{\prime \prime}$ $\mathrm{W} ; 464 \mathrm{~m}$ ) of the $N$. aurispinosus specimen was $1 \mathrm{~km}$ to the north of the locality of Tomasiri, Inclán district, Tacna province in Tacna department, Perú on August 1 $1^{\text {st }}, 2015$, during the wet season in a study about the diversity of bats in the Sama valley. The research involved a total of six sampling stations, each with seven mist-nets open 11 hours (from 18:00 to 5:00 hours) during four nights per station and season of evaluation (wet and dry), with a cumulative sampling effort of 3,696 hours/net/night. The research was authorized through permit R.D. №246-2017-SERFOR/DGGSPFFS and authorization code with purposes of scientific research AUT-IFS-2017-057.

The specimen was an adult male in reproductive condition captured in a mist-net placed perpendicular to the main course of Sama river, which was found drowned due to the low flight of Anas georgica at the moment of the collection. The sampling station was close to a hillside of semi-consolidated gravel with coarse river sand and clay that reaches $50 \mathrm{~m}$ of height with regard to the ground. The riparian forest to the riversides is narrow and for the right presents a wide extension of agricultural crops.

The specimen was identified preliminarily as N. aurispinosus because of its external characteristics and measurement of the forearm using the taxonomic key of Díaz et al. (2016), being later preserved in alcohol with the skull removed. Following Freeman (1981) and Velazco and Solari (2003), the following external and cranio-dental measurements were taken with a digital vernier $( \pm 0.01 \mathrm{~mm})$ for the accurate identification of the species: total body length, $\mathrm{TL}$; tail length, $\mathrm{T}$; length of hind foot, HF; ear length, $\mathrm{E}$; total weight, Wt (in grams); greatest length of skull, GLS; condyloincisive length, CIL; postorbital breadth, $\mathrm{POB}$; maxillary toothrow length, $\mathrm{CM}$; upper molar breadth, $\mathrm{MM}$; upper canine breadth, CC; zygomatic breadth, ZB; mastoid breadth, MAB; braincase breadth, $B C B$; greatest length of mandible, GLM; lower toothrow length, $\mathrm{Cm}$; length of forearm, FA; length of third metacarpal, III MET; total length of fourth metacarpal, IV MET; total length of fifth metacarpal, V MET. These morphological characteristics were compared with other specimens of $N$. aurispinosus (MUSM 235 and MUSM 6051) deposited in the Museo de Historia Natural de la Universidad Nacional Mayor de San Marcos (Table 1).

In order to elaborate the current distribution of the species, we reviewed 78 records covered in other studies (Peale 1848; Sanborn 1941; Ortiz de la Puente 1951; Carter and Davis 1961; Gardner 1962a, 1962b; Álvarez 1963; Gardner 1963; Álvarez and Aviña 1964; Jones and Álvarez 1964; Baker et al. 1967; Linares 1969; Baker and Jones 1972; Taddei and Garutti 1981; Ochoa 1984; Ibáñez and Ochoa 1989; Silva et al. 1996; Anderson 1997; Pedro et al. 2001; Bredt 2003; López-González and García-Mendoza 2006; Eger 2008; Bianconi et al. 2009; Tavares et al. 2010; Velazco et al. 2013; Dolman and Ammerman 2015; Pari et al. 2015; Espinal et al. 2016; Garbino 2016; Oliveira et al. 2019), which reported specimens deposited in the following scientific collections:
American Museum of Natural History (AMNH), Colección de Mastozoología, Centro de Ecología y Biodiversidad, Lima, Perú (CEBIOMAS), Colecão de Chiroptera do Departamento de Zoologia da Universidade Estadual Paulista, São José do Rio Preto (DZSJRP), Colecão de Mamíferos, Universidade Federal de Lavras (UFLA), Colecão de Mamíferos, Universidade Federal de Minas Gerais (UFMG), Colección Privada de Omar Linares $(\mathrm{OL})$, Collection of Recent Mammals, Museum of Texas Tech University (TTU), Estación Biológica de Doñana (EBD_MAM), Field Museum of Natural History (FMNH), Instituto de Biología de la Universidad Autónoma de México (IB), Instituto Politécnico Nacional, Colección Regional de Durango (CRD), Louisiana State University Museum of Zoology, Baton Rouge, Louisiana, USA (LSUMZ), Mammal Collection, University of Arizona Museum of Natural History (UAZ), Museo de Biología de la Universidad Central de Venezuela (MBUCV), Museo de Historia Natural de la Universidad Nacional Mayor de San Marcos (MUSM), Museo de la Estación Biológica de Rancho Grande (EBRG), Museum of Zoology of the University of São Paulo / Museu de Zoologia da Universidade de São Paulo (MZUSP), University of Kansas, Natural History Museum and Biodiversity Research Center (KU), United States National Museum of Natural History (USNM), Texas A\&M University, Texas Cooperative Wildlife Collections (TCWC), The Field Museum of Natural History (FMNH), and Michigan State University (MSU; Appendix I).

In addition, to characterize the digestive tract contents, a ventral incision was made to open the digestive tube and separate it in small portions. Its contents were placed over Petri plates and scattered in distilled water with help of stilettos, the samples of interest were preserved in alcohol of 96 (Shiel et al. 1997; Vidal-Martínez et al. 2002; CaspetaMandujano et al. 2007). Finally, the keys of Whitaker et al. (2009) and Whitaker and Castor (2010) were used for identification under a stereomicroscope at 40 and 100X magnifications in the Laboratory of Genetics of the Universidad Nacional Jorge Basadre Grohmann.

The study area of the new record of $N$. aurispinosus located in the Sama valley is surrounded by great desertic areas, cracks, and riverbeds of scarce flow with xeric vegetation (families Anacardiaceae, Asteraceae, Cupressaceae, Fabaceae, and Poaceae). It is geographically located where the Coastal Desert of Perú finishes, and the Atacama Desert begins in Chile. This valley is one of the most important of Tacna department, principally dedicated to agricultural (crops of alfalfa, peppers, onion, corn, and olive) and livestock activities (caprine, equine, porcine, ovine, and bovine cattle).

After external and cranial comparisons with MUSM 235 and MUSM 6051 and based on the original description of N. aurispinosus (Peale 1848) and its subsequent re-description (Casssin 1858), our specimen (GPZ 001) presented the diagnostic characters for the species, which are described as follows: at external level, the dorsal and ventral fur is short, dense, fine and of chestnut brown color lighter in the base of the hair with tips that give it a silver appearance under the light, wing membranes are brown-violet, ears are big 


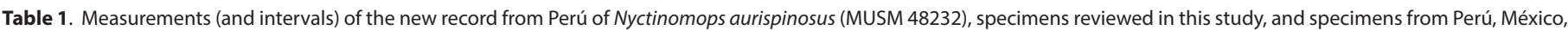
Colombia, Venezuela, Brazil, and Bolivia. The abbreviations are specified in the text.

\begin{tabular}{|c|c|c|c|c|c|c|c|c|c|c|c|c|c|c|}
\hline \multirow{2}{*}{$\begin{array}{c}\text { Measurement } \\
\text { Sex }\end{array}$} & \multirow{2}{*}{$\begin{array}{c}\text { MUSM } \\
48232 \\
\text { M }\end{array}$} & \multirow{2}{*}{$\begin{array}{c}\text { MUSM } \\
6051\end{array}$} & \multicolumn{2}{|c|}{ Perú $A, B$} & \multicolumn{2}{|c|}{ México $^{B, C, D, E, F, G, H, I}$} & \multirow{2}{*}{$\begin{array}{c}\text { Colombia } \\
\text { M }\end{array}$} & \multicolumn{2}{|c|}{ Venezuela $^{\mathrm{K}}$} & \multicolumn{3}{|c|}{ Brazill, M,N } & \multicolumn{2}{|c|}{ Bolivia ${ }^{\circ}$} \\
\hline & & & $M$ & $\mathrm{~F}$ & $M$ & $F$ & & $M$ & $F$ & $M$ & $M$ & $M$ & $M$ & $F$ \\
\hline & & & & & 20.4 & 20.02 & & & 21.6 & & & & & \\
\hline \multirow[t]{3}{*}{ GLS } & 19.45 & 19.38 & 20 & 20.8 & $(18.7-21.6)$ & $(17.9-20.8)$ & 20.7 & 21.7 & $(21.7-21.4)$ & & & & & \\
\hline & & & & & 17 & 12 & & & 2 & & & & & \\
\hline & & & & & 18.47 & 17.7 & & & & & & & 18.9 & 19.6 \\
\hline \multirow[t]{3}{*}{ CIL } & 18.43 & & 18.8 & 19.1 & $(17.6-20)$ & $(16.9-19.1)$ & 18.8 & & & 19.9 & & & $(18.7-19.2)$ & $(19-20.5)$ \\
\hline & & & & & 14 & 11 & & & & & & & 4 & 4 \\
\hline & & & & & 3.73 & 3.67 & & & 4.4 & & & & 3.8 & 3.9 \\
\hline \multirow[t]{3}{*}{ POB } & 3.72 & 3.64 & 3.7 & 3.6 & $(3.5-4)$ & $(3.4-3.8)$ & 3.9 & 4.7 & $(4.5-4.2)$ & 3.6 & & & $(3.7-3.9)$ & $(3.9-4)$ \\
\hline & & & & & 16 & 11 & & & 2 & & & & 4 & 4 \\
\hline & & & & & 7.65 & 7.46 & & & 8.4 & & & & 7.9 & 8 \\
\hline \multirow[t]{3}{*}{$\mathrm{CM}$} & 7.40 & 7.30 & 7.8 & 7.8 & $(6.8-8.2)$ & $(6.9-7.8)$ & 7.8 & 8.5 & $(8.4-8.3)$ & 8.1 & 8.1 & 7.9 & $(7.8-8)$ & $(7.9-8.1)$ \\
\hline & & & & & 17 & 13 & & & 2 & & & & 4 & 4 \\
\hline & & & & & 8.17 & 8.2 & & & 9.1 & & & & 8.4 & 8.7 \\
\hline \multirow[t]{3}{*}{ MM } & 7.83 & 7.96 & 806 & 8.4 & $(7.3-8.5)$ & $(7.2-8.6)$ & & 9.4 & $(9.1-9)$ & 8.2 & 8.3 & & $(8.3-8.6)$ & $(8.6-8.7)$ \\
\hline & & & 0.00 & & 17 & 11 & & & 2 & & & & 4 & 4 \\
\hline & & & & & 4.47 & 4.55 & & & 5.1 & & & & & \\
\hline \multirow[t]{3}{*}{ CC } & 4.71 & 4.58 & 4.58 & 4.8 & $(4.1-4.8)$ & $(4.2-4.9)$ & 4.7 & 5.3 & $(5.1-5)$ & 4.7 & 4.7 & & & \\
\hline & & & & & 6 & 4 & & & 2 & & & & & \\
\hline & & & & & 11.59 & 11.43 & & & 12.1 & & & & 11.7 & 12 \\
\hline \multirow[t]{3}{*}{ ZB } & 11.16 & 11.2 & 11.2 & 11.7 & $(11.1-12)$ & $(11-11.8)$ & 11.6 & 12.7 & $(12.1-12)$ & 11.9 & & & $(11.5-11.8)$ & $(11.7-12.1)$ \\
\hline & & & & & 14 & 12 & & & 2 & & & & 4 & 4 \\
\hline & & & & & 10.85 & 11.05 & & & 11.1 & & & & & \\
\hline \multirow[t]{3}{*}{ MAB } & 9.60 & 9.59 & & 10.9 & $(10.2-11.3)$ & $(11-11.1)$ & 10.4 & 11.7 & $(11.1-11)$ & 11.1 & & & & \\
\hline & & & & & 6 & 2 & & & 2 & & & & & \\
\hline & & & & & 9.37 & 9.22 & & & 9.6 & & & & & \\
\hline \multirow[t]{2}{*}{$\mathrm{BCB}$} & 9.52 & & 9 & 9.5 & $(9.1-9.7)$ & $(8.9-9.5)$ & 9.3 & 10.4 & $(9.6-9.5)$ & 9.3 & & & & \\
\hline & & & & & 13 & 11 & & & 2 & & & & & \\
\hline \multirow[t]{2}{*}{ GLM } & 14.15 & 13.79 & 13.6 & & & & & & & 15 & 15.5 & 14.1 & & \\
\hline & & & & & 8.33 & 8.1 & & & & & & & & \\
\hline $\mathrm{Cm}$ & 8.1 & 8.22 & 8.5 & 8.9 & $(7.7-9.4)$ & $(7.5-9)$ & 8.5 & & & 8.7 & 8.6 & 8.6 & & \\
\hline & & & & & 11 & 10 & & & & & & & & \\
\hline & & & & & 48.23 & 47.67 & & & 54.9 & & & & 49.7 & 51 \\
\hline FA & 50 & & 48 & 51.4 & $(47.1-50.4)$ & $(42.4-49.8)$ & 49.5 & 55.3 & $(55.7-54.2)$ & 51.5 & 53.4 & 51.6 & $(48.7-50.3)$ & $(50.3-52.8$ \\
\hline & & & & & 16 & 13 & & & 2 & & & & 4 & 4 \\
\hline & & & & & 48.76 & 47.6 & & & 54.3 & & & & & \\
\hline III MET & 50 & & 48 & 48.4 & $(47.9-49.9)$ & $(46.2$ - 48.6) & 49 & 56.5 & $(54.6-54)$ & 51 & 51.6 & 49.4 & & \\
\hline & & & & & 9 & 10 & & & 2 & & & & & \\
\hline & & & & & 47.32 & 46.16 & & & 53.3 & & & & & \\
\hline IV MET & 49 & & 46.3 & 46.8 & $(46.7-48.5)$ & $(44.9-47.7)$ & 46.2 & 54.2 & $(53-52.6)$ & 50.6 & 50.7 & 47.8 & & \\
\hline & & & & & 9 & 9 & & & 2 & & & & & \\
\hline & & & & & 27.88 & 27.32 & & & 29.8 & & & & & \\
\hline V MET & 28.5 & & 26 & 26.9 & $(26.6-29.2)$ & $(26-28.5)$ & 27.5 & 31.7 & $(30.4-29.1)$ & 31 & 28.9 & 27.3 & & \\
\hline & & & & & 9 & 9 & & & 2 & & & & & \\
\hline
\end{tabular}

A: Ortiz de la Puente (1951), B: Carter and Davis (1961), C: Gardner (1962a, 1962b), D: Gardner (1963), E: Álvarez and Aviña (1964), F: Baker et al. (1967), G: Baker and Jones (1972), H: Anderson (1997), I: López-González and García-Mendoza (2006), J: Sanborn (1941), K: Ochoa (1984), L: Taddei and Garutti (1981), M: Bianconi et al (2009), N: Oliveira et al. (2019), O: Ibáñez and Ochoa (1989). M = Male, F = Female. 
and united to the front with presence of small thorn-shape protuberances (from 6 to 8 ) in their anterior margin, the upper lips wrinkled, the nostrils rounded of lengthened edges with small stiff bristles and the feet with large vibrissa (Figure 1a-f). The skull is large and narrow with a rounded dorsal contour and bulky frontal region, upper incisors are parallel and divided by a narrow emargination of the palate, the posterior margin of which is at the level of the posterior border of the third molars (Shamel 1931; Gardner 1963). The basisphenoid pits are moderately deep (Eger 2008; Gregorin and Ciranello 2015) and the sagittal crest is slightly developed (Jones and Arroyo-Cabrales 1990; Figure 2).

The specimen has the following external measurements: $\mathrm{TL}=106 \mathrm{~mm}, \mathrm{~T}=48 \mathrm{~mm}, \mathrm{HF}=8 \mathrm{~mm}, \mathrm{E}=21 \mathrm{~mm}$, and $\mathrm{Wt}=14.5 \mathrm{~g}$. Moreover, the forearm has a length of $50 \mathrm{~mm}$ and a total length of the skull of $19.45 \mathrm{~mm}$ and other measurements that were compared with the reported for the records of $N$. aurispinosus of Ortiz de la Puente (1951) and Carter and Davis (1961) for Perú; Carter and Davis (1961), Gardner (1962a, 1962b), Gardner (1963), Álvarez and Aviña (1964), Baker et al. (1967), Baker and Jones (1972), Anderson (1997), and López-Gonzáles and García-Mendoza (2006) for México; Sanborn (1941) for Colombia; Ochoa (1984) for Venezuela; Taddei and Garutti (1981), Bianconi et al. (2009), and Oliveira et al. (2019) for Bolivia, evidencing that is inside

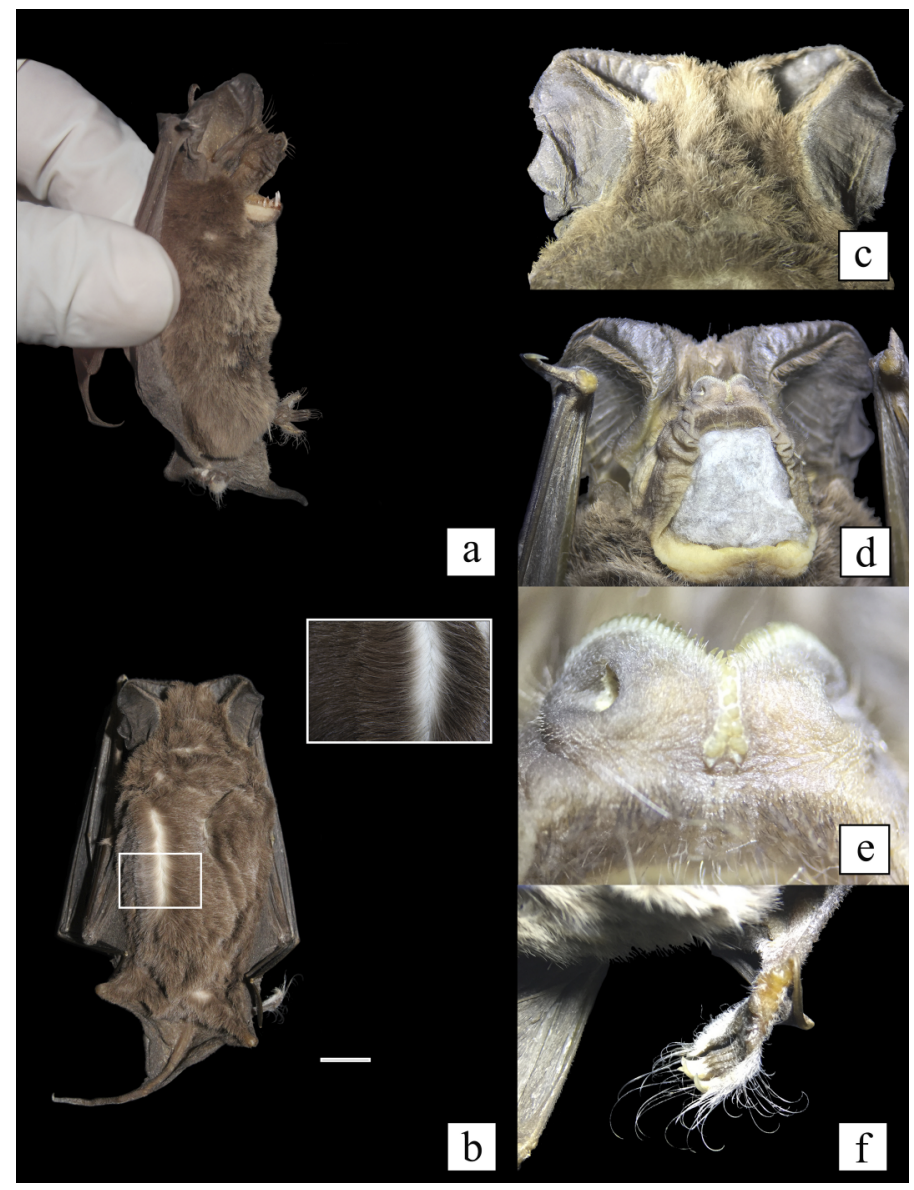

Figure 1. Male adult specimen of $N$. aurispinosus (MUSM 48232), fur characteristics are observed. a) Lateral view of the specimen. b) Dorsal view of the specimen. c) Presence of spine-shaped bumps on the anterior margin of the ears. d) Presence of big ears joined to the front. e) Presence of small stiff bristles at the edge of the nostrils. $f$ ) Presence of vibrissa in the hind legs. Scale bar: $5 \mathrm{~mm}$.

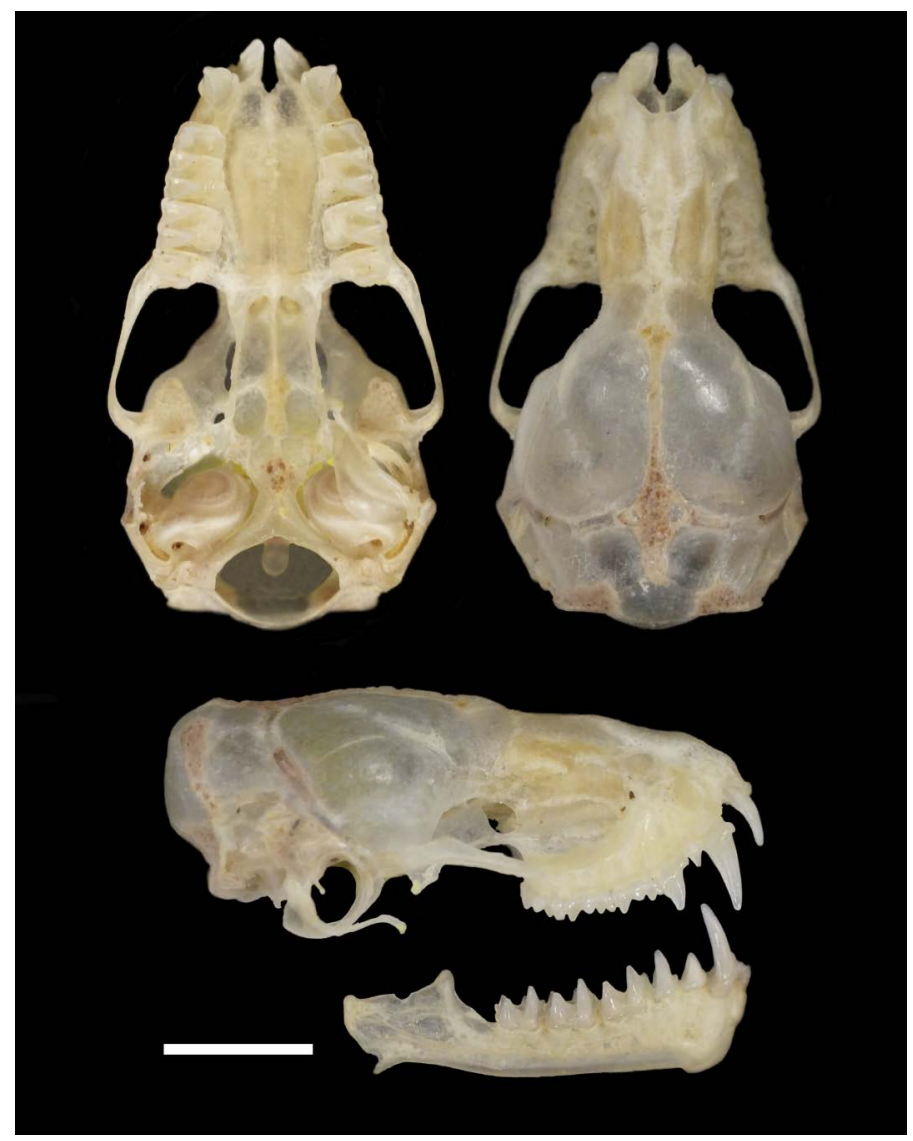

Figure 2. Ventral, dorsal, and lateral views of the skull of Nyctinomops aurispinosus (MUSM 48232). Scale bar: $5 \mathrm{~mm}$.

the range of size of the species. Our specimen was deposited as MUSM 48232 in the scientific collection of the Mammalogy department of the Museo de Historia Natural de la Universidad Nacional Mayor de San Marcos.

The current distribution map of $N$. aurispinosus in the Neotropics was elaborated from 78 records referred in scientific publications (Figure 3 ). On the other hand, the digestive tract content analysis uncovered remains of insects corresponding to $100 \%$ lepidopterans, consisting of antennas, scales, legs, and proboscis (galeas that compounds the proboscis; Figure 4 a-f).

Nyctinomops aurispinosus is considered a rare species due to the relatively few specimens in scientific collections (Bianconi et al. 2009) and infrequent captures related to its sophisticated system of echolocation and flight at high altitudes; these characteristics of most molossids make their capture difficult with mist-nets (Norberg and Rayner 1987; Kalko et al. 1996; Voss and Emmons 1996).

In this study, we present the current distribution and the first record of $N$. aurispinosus for Tacna department, Perú. This finding represents the southernmost report for the Pacific coast, extending the geographical distribution of $N$. aurispinosus ca. $270 \mathrm{~km}$ to the south, from the previous record of the species in Arequipa department (Pari et al. 2015). The presence of $N$. aurispinosus in the extreme south of Perú is consistent with other records of the species along the American tropics and sub-tropics (Eger 2008; Bianconi et al. 2009; Espinal et al. 2016). 


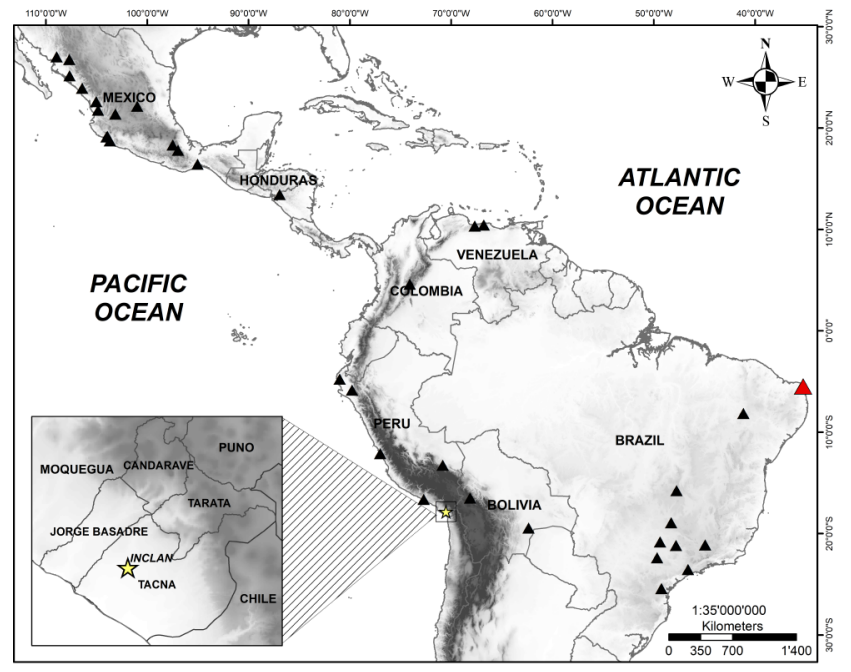

Figure 3. Geographic distribution of Nyctinomops aurispinosus in México, Honduras, Colombia, Venezuela, Brazil, Bolivia, and Perú $(\boldsymbol{\Delta})$; type locality $(\boldsymbol{\Delta})$; including the new southernmost record from Perú ( $\hat{\xi})$ (MUSM 48232).

The record of $N$. aurispinosus over the course of Sama river is consistent with reports of the species near freshwater bodies, such as streams, puddles, and rivers in México and Bolivia (Gardner 1962a, 1962b, 1963; Baker et al. 1967; Baker et al. 1972; Wilson 1985; Ibáñez and Ochoa 1989); these may relate to the foraging behavior of molossids at great height, but they are also captured with mist-nets over fresh water sources when descending to drink (Voss and Emmons 1996). The majority of the records of the species are associated to coastal places at low altitude (Álvarez and Aviña 1964; Wilson 1985), suggesting that it prefers low and warm zones, again in agreement with the zone of the new record.

The roosts that N. aurispinosus probably uses in the Sama valley are rock cracks in steep slopes, as has been observed for Mormopterus kalinowskii, Promops davisoni, and Tadarida brasiliensis in nearby valleys (Aragón and Aguirre 2014; Flores-Quispe et al. 2019). Previous reports referred to its occupation of cracks and caves with other molossids (Ortiz de la Puente 1951; Sanborn 1951; Carter and Davis 1961; Álvarez 1963), as well as high-rise human constructions (Taddei and Garutti 1981; Ochoa 1984; Bianconi et al. 2009).

The specimen (MUSM 48232), as shown in Table 1, has external and cranial measurements slightly smaller than reported by other studies. Additional studies are needed to determine whether size variation in the species is significant.

The analysis of the digestive tract contents showed the remains of lepidopterans, as occurs for $N$. macrotis and $N$. femorosaccus in studies about their diets (Ross 1967; Easterla and Whitaker 1972; Sparks and Valdez 2003; Debelica et al. 2006; Matthews et al. 2010). Molossids with long thin teeth, which are characteristic of the genus Nyctinomops, have a wide gape and can feed on large flying insects, provided that they have a soft consistency (Freeman 1979).

Previously, nine bat species were reported for Tacna department (Amorphochilus schnablii, Desmodus rotundus, Histiotus macrotus, H. montanus, Mormopterus kalinowskii, Myotis atacamensis, Platalina genovensium, Promops davi-

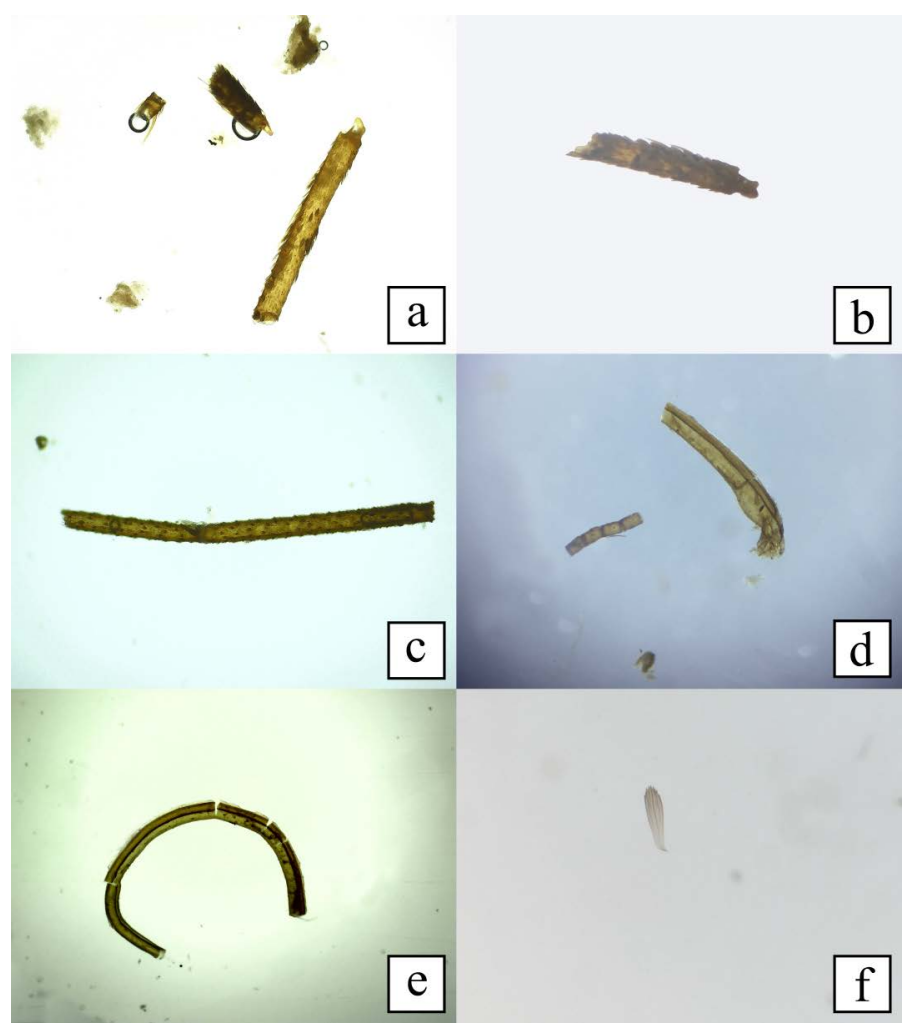

Figure 4. Remains of lepidoptera found in the digestive tract of the specimen MUSM 48232. a) Scales and leg. b) and c) Tibia. d) Section of the flagellum of an antenna and portion of proboscis. e) Proboscis: galeas that compound the proboscis. f) Scale.

soni and Tadarida brasiliensis; Aragón and Aguirre 2014; Flores-Quispe et al. 2015). The new record of N. aurispinosus (MUSM 48232) brings to ten the number of species recorded in the department. In the same way, the proximity of the record and the similarity among the habitats of the Peruvian south and the Chilean north suggests that $N$. aurispinosus may also occur in Chile, similarly to the proposal by Flores-Quispe et al. (2015) for Promops davisoni, which was recently confirmed by Ossa et al. (2018).

The new record and range extension presented in this work fill information gaps about the distribution and ecology of N. aurispinosus. Therefore, we recommend the development of more studies in order to obtain a better approximation about the diversity of bats in the extreme south of Perú.

\section{Acknowledgements}

We thank L. Montes de Oca and G. Ticona for their help in the field and cabinet phases, respectively, K. Neyra for her help concerning the flora in the study area, P. Sánchez for her comments and suggestions, and V. Romero, F. García, and R. Van Horn for their kindnesses in sending us various bibliographic references. Our deepest acknowledgement to A. Gardner for the kindness of sending us skull measurements of $N$. aurispinosus that he took from the specimens he reviewed and B. Patterson and S. Velazco for their time, patience and meticulousness in improving the language and giving us accurate and valuable considerations about this manuscript. Finally, we thank J. Ticona, J. Callohuari, and P. Ancajima for their help with ornithological and entomological identifications. 


\section{Literature cited}

Aguiar, L. M. S., A Motta, and C. E. L. Esbérard. 2012. Falco sparverius (Aves: Falconiformes) preying upon Nyctinomops laticaudatus (Chiroptera: Molossidae). Zoologia 29:180-182.

Álvarez, T. 1963. The Recent Mammals of Tamaulipas, Mexico. University of Kansas Publications Museum of Natural History 14:363-473.

Álvarez, T., And C. E. Aviña. 1964. Nuevos registros en México de la familia Molossidae. Revista de la Sociedad Mexicana de Historia Natural 25:243-254.

Ammerman, L. K., D. N. Lee, AND M. Tipps. 2012. First molecular phylogenetic insights into the evolution of free-tailed bats in the subfamily Molossinae (Molossidae, Chiroptera). Journal of Mammalogy 93:12-28.

Anderson, S. 1997. Mammals of Bolivia, taxonomy and distribution. Bulletin of the American Museum Natural History 231:1-652.

Aragón, G., And M. Aguirre. 2014. Distribución de murciélagos en la región de Tacna (Perú). Idesia 32:119-127.

Baker, R. H., R. G. WebB, AND P. Dalby. 1967. Notes on Reptiles and Mammals from Southern Zacatecas. American Midland Naturalist 77:223-226.

BakeR, R. J., AND J. K. Jones, JR. 1972. Tadarida aurispinosa in Sonora, México. The Southwestern Naturalist 17:293-312.

Bianconi, G., R. Gregorín, And D. Carneiro. 2009. Range extension of the Peale's Free-tailed Bat Nyctinomops aurispinosus (Molossidae) in Brazil. Biota Neotropica 9:267-270.

Bredt, A. 2003. A experiência do Distrito Federal. In Manejo de quirópteros em áreas urbanas. Pp. 24-28 in Manual Técnico do Instituto Pasteur (I. Kotait et al., orgs.). Instituto Pasteur, Fundação Nacional de Saúde, Ministério da Saúde, São Paulo. 7, Seminário Comemorativo dos 100 Anos do Instituto Pasteur.

Carter, D., And W. Davis. 1961. Tadarida aurispinosa (Peale) (Chiroptera:Molossidae) in North America. Proceedings of the Biological Society of Washington 74:161-166.

Caspeta-Mandujano, J. M., J. L. Peralta-Rodríguez, S. B. RamírezChávez, S. E. Ramírez-Díaz, M. Tapia-Osorio, M. G. Juárez, J. A. Guerrero, M. G. Galindo, G. Martínez, M. C. P. OJeda, and V. JuÁrez. 2017. Helmintos Parásitos de Murciélagos en México. Universidad Autónoma del Estado de Morelos, Praxis Digital Editor, S. A. Ciudad de México, México.

Cassin, J. 1858. Mammalogy and Ornithology. United States Exploring Expedition during the years 1838, 1839, 1840, 1841,1842 under the command of Charles Wilkes, U.S.N. C. Sherman and Son. Philadelphia, U.S.A.

Debelica, A., A. K. Matthews, And L. K. Ammerman. 2006. Dietary study of big free-tailed bats (Nyctinomops macrotis) in Big Bend National Park. The Southwestern Naturalist 51:414-418.

Díaz, M. 2011. New record of bat from the northern region of the Peruvian Amazon. Zoological Research 32:1-11.

Díaz, M., S. Solari, L. Aguirre, L. Aguilar, and R. Barquez. 2016. Clave de identificación de murciélagos de Sudamérica. Publicación Especial N², PCMP (Programa de Conservación de Murciélagos de Argentina). Tucumán, Argentina.

Dolman, R., And L. Ammerman. 2015. Molecular systematics of Nyctinomops (Chiroptera: Molossidae). Western North American Naturalist 75:43-51.
Easterla, D. A., AND J. O. Whitaker, JR. 1972. Food habits of some bats from Big Bend National Park, Texas. Journal of Mammalogy 53:887-890.

Eger, J. L. 2008. Family Molossidae. Pp. 399-440 in Mammals of South America: marsupials, xenarthrans, shrews, and bats (Gardner, A. L., ed.). University of Chicago Press. Chicago, U.S.A.

Espinal, M., J. Mora, And C. O'Reilly. 2016. The occurrence of the Peale's free-tailed bat (Nyctinomops aurispinosus, Molossidae) in Central America. Caribbean Journal of Science 49:79-82.

Flores-Quispe, M., G. Calizaya, V. Pacheco, and G. Aragón. 2015. Distribution of Promops davisoni Thomas, 1921 (Chiroptera: Molossidae) in Peru with a new record and southward range extension. Check List 11:1573.

Flores-Quispe, M., G. Calizaya, G. Portugal-Zegarra, G. A. Aragón, J. Pacheco-Castillo, and E. M. Rengifo. 2019. Contributions to the natural history of Mormopterus kalinowskii (Chiroptera: Molossidae) in the southwest of Peru. Therya 10:343-352.

Freeman, P. W. 1979. Specialized insectivory: beetle-eating and moth-eating molossid bats. Journal of Mammalogy 60:467-479.

Freeman, P. W. 1981. A Multivariate Study of the Family Molossidae Mammalia, Chiroptera): Morphology, Ecology, Evolution. Fieldiana Zoology 7:1-173.

Garbino, G. S. T. 2016. Research on bats (Chiroptera) from the state of São Paulo, southeastern Brazil: Annotated species list and bibliographic review. Arquivos de Zoologia, Museu de Zoologia da Universidade de São Paulo 47:43-128.

GARDNER, A. L. 1962a. Bat records from the Mexican States of Colima and Nayarit. Journal of Mammalogy 43:102-104.

Gardner, A. L. 1962b. Correction. Journal of Mammalogy 43:537.

Gardner, A. L. 1963. Nota acerca de la distribución de dos murciélagos en México. Revista de la Sociedad Mexicana de Historia Natural 24:41-44.

Gregorin, R., And E. A. Chiquito. 2010. Revalidation of Promops davisoni Thomas (Molossidae). Chiroptera Neotropical 16:648-660.

Gregorin, R., And A. Cirranello. 2015. Phylogeny of Molossidae Gervais (Mammalia: Chiroptera) inferred by morphological data. Cladistics 32:1-34.

IBÁÑEz, C., AND J. OchoA. 1989. New Records of Bats from Bolivia. Journal of Mammalogy 70:216-219.

Jones, J. K., JR., AND T. Álvarez. 1962. Taxonomic status of the free-tailed bat, Tadarida yucatanica Miller. University of Kansas Publications, Museum of Natural History 9:125-133.

Jones, J. K., JR., ANd T. Álvarez. 1964. Additional Records of Mammals from the Mexican State of San Luis Potosi. Journal of Mammalogy 45:302-303.

Jones, J. K., JR., And J. Arroyo-Cabrales. 1990. Nyctinomops aurispinosus. Mammalian Species 350:1-3.

Kalko, E. K. V., JR., C.O. Handley, ANd D. Handley. 1996. Organization, diversity, and long-term dynamics of a Neotropical bat community. Pp. 503-553 in Long-term Studies in Vertebrate Communities (Cody, M., and J. Smallwood, eds.). Academic Press, Los Angeles, U.S.A.

Kraker-Castañeda, C., S. G. Pérez, J. O. Cajas-Castillo, and J. L. Echeverría-Tello. 2016. Lista actualizada de los murciélagos 
(Mammalia, Chiroptera) de Guatemala. Revista Mexicana de Biodiversidad 87:409-416.

LinARES, O. 1969. Quirópteros subfosiles encontrados en las Cuevas Venezolanas Parte II Tadarida aurispinosa (Peale) en la cueva de los Carraos (MI.14), Miranda. Boletín de la Sociedad Venezolana de Espeleología 1:119-145.

López-González, C., And D. F. García-Mendoza. 2006. Murciélagos de la Sierra Tarahumara, Chihuahua, México. Acta Zoológica Mexicana 22:109-135.

Loureiro, L. O., B. K. Lim, And M. D. Engstrom. 2018. A new species of mastiff bat (Chiroptera, Molossidae, Molossus) from Guyana and Ecuador. Mammalian Biology 90:10-21.

Málaga, B. A., D. R. Díaz, S. Arias, and C. E. Medina. 2020. Una especie nueva de Lasiurus (Chiroptera: Vespertilionidae) del suroeste de Perú. Revista Mexicana de Biodiversidad 91:e913096.

Matthews, A. K., S. A. Neiswenter, and L. K. Ammerman. 2010. Trophic ecology of the free-tailed bats Nyctinomops femorosaccus and Tadarida brasiliensis (Chiroptera: Molossidae) in Big Bend National Park, Texas. The Southwestern Naturalist 55:340-346.

McCarthy, T. J., ANd M. Blake. 1987. Noteworthy bat records from the Maya Mountains Forest Reserve, Belize. Mammalia 51:161-164.

McCarthy, T. J., W. B. Davis, J. E. Hill, J. K. Jones JR., And G. A. CRUz. 1993. Bat (Mammalia: Chiroptera) records, early collectors, and faunal lists for northern Central America. Annals of the Carnegie Museum 62:191-228.

Medina, C. E., A. Pari, W. Delgado, H. T. Zamora, H. Zeballos, And K. PIno. 2012. First occurrence of Eumops patagonicus (Chiroptera: Molossidae) and range expansion of the geographic distribution of E. hansae, in Peru. Mastozoología Neotropical 19:345-351.

Medina, C. E., R. Gregorín, H. Zeballos, H. T. Zamora, and L. M. Moras. 2014. A new species of Eumops (Chiroptera: Molossidae) from southwestern Peru. Zootaxa 3878:19-36.

Medina-Fitoria, A., O. Saldaña, J. G. Martínez, Y. Aguirre, W. Silva, M. Chávez, M. Salazar, N. Carballo, O. Jarquín, R. A. Gonzales, L. Diaz, C. Chambers, F. Reid, R. Mais, K. Williams, J. M. Zoloto, C. Molina, T. Pérez, J. Rodríguez, L. E. Gutiérrez, M. Fernández, R. Mendieta, And J. Perez. 2015. Nuevos reportes y comentarios sobre los murciélagos (Mammalia: Chiroptera) de Nicaragua, América Central, con la adición de siete nuevas especies para el país. Mastozoología Neotropical 22:43-54.

Miller, G. 1902. Twenty New American Bats. Proceedings of the National Academy of Sciences 54:389-412.

Milner, J., C. Jones, And J. K. Jones JR. 1990. Nyctinomops macrotis. Mammalian Species 351:1-4.

Moras, L., R. Gregorín, T. H. Sattler, and V. Da C. Tavares. 2018. Uncovering the diversity of dog-faced bats of the genus $\mathrm{Cy}$ nomops (Chiroptera: Molossidae), with the redescription of $C$. milleri and the description of two new species. Mammalian Biology 89:37-51.

Norberg, U. M., and J. M. V. Rayner. 1987. Ecological morphology and flight in bats (Mammalia; Chiroptera): wing adaptations, flight performance, foraging strategy and echolocation. Philosophical Transactions of The Royal Society B Biological Sciences 316:335-427.

NowaK, R. M. 1994. Walker's bats of the world. Johns Hopkins University Press, Baltimore, U.S.A.
Ocноя, J. 1984. Presencia de Nyctinomops aurispinosa en Venezuela. Acta Científica Venezolana 35:147-150.

Oliveira, F., T. D. Almeida, And R. Stumpp. 2019. New record of the rare peale's free-tailed bat, Nyctinomops aurispinosus (Peale, 1848) (Chiroptera: Molossidae), for the Cerrado of southeastern Brazil. Oecologia Australis 23:690-697.

Ortiz de la Puente, D. J. 1951. Estudio monográfico de los quirópteros de Lima y alrededores. Publicaciones del Museo de Historia Natural "Javier Prado", Universidad Nacional Mayor de San Marcos 7:1-48.

Ossa, G., T. M. Lilley, J. Ugarte-Núñez, L. Ruokolainen, K. Vilches, P. Valladares-Faúndez, and V. Yung. 2018. First record of Promops davisoni (Thomas, 1921) (Chiroptera, Molossidae) from Chile and a description of its echolocation calls. Mastozoología Neotropical 25:129-137.

Owen, J. G. AND L. Girón. 2012. Revised checklist and distributions of land mammals of El Salvador. Occasional Papers, Museum Texas Tech University 310:1-32.

Pacheco, V., R. Cadenillas, E. Salas, C. Tello, and H. Zeballos. 2009. Diversidad y endemismo de los mamíferos del Perú. Revista Peruana de Biología 16:05-32.

Pari, A., K. Pino, C. Medina, E. López, and H. Zevallos. 2015. Murciélagos de Arequipa, Historial Natura y Conservación. Arequipa, Perú.

Peale, T. 1848. Mammalia and Ornithology. United States Exploring Expedition during the years 1838, 1839, 1840, 1841, 1842 under the command of Charles Wilkes, U.S.N. C. Sherman and Son. Philadelphia, U.S.A.

Pedro, W. A., F. C. Passos, ANd B. K. Lim. 2001. Morcegos (Chiroptera; Mammalia) da Estação Ecológica dos Caetetus, estado de São Paulo. Chiroptera Neotropical 7:136-140.

Peracchi, A. L., I. P. Lima, N. R. Reis, M. R. Nogueira, and H. Ortencı-Fıннo. 2011. Orden Chiroptera. Pp. 155-234 in Mamíferos do Brasil (Reis, N. R., A. L. Peracchi, W. A. Pedro, and I. P. Lima, eds.). Volume II. Londrina: Nelio R. dos Reis.

Ross, A. 1967. Ecological aspects of the food habits of insectivorous bats. Proceedings Western Foundation of Vertebrate Zoology 1:205-264.

Sanborn, C. C. 1941. Descriptions and records of Neotropical bats. Field Museum of Natural History, Zoological Series 27:371-387.

Sanborn, C. C. 1951. Mammals from Marcapta, Southeastern Peru. Publicaciones del Museo de Historia Natural "Javier Prado" 6:1-26.

Shamel, H. 1931. Notes on the American Bats of the Genus Tadarida. Proceedings of the United States National Museum 78:1-27.

Shiel, C. B., C. M. McAney, C. Sullivan, and J. S. Fairley. 1997. Identification of arthropod fragments in bat droppings. Occasional publication Mammal Society no. 17. The Mammal Society, London.

Silva-Taboada, G., ANd K. F. Koopman. 1964. Notes on the occurrence and ecology of Tadarida laticaudata yucatanica in eastern Cuba. American Museum Novitates 2174:1-6.

Silva, M. M. S., N. M. S. Harmani, E. F. B. Gonçalves, and W. UieDA. 1996. Bats from the Metropolitan Region of São Paulo, Southeastern Brazil. Chiroptera Neotropical 2:39-41.

Sımmons, N. B. 2005. Order Chiroptera. Pp. 312-529 in Mammal Species of the World: a Taxonomic and Geographic Reference 
(Wilson, D. E., and D. M. Reeder, eds.). Third edition. Johns Hopkins University Press, Baltimore, U.S.A.

Solari, S., ANd V. Martínez-Arias. 2014. Cambios recientes en la sistemática y taxonomía de murciélagos neotropicales (Mammalia: Chiroptera). Therya 5:167-196.

Soto-Centeno, J. A., N. B. Simmons, and D. W. Steadman. 2017. The bat community of Haiti and evidence for its long-term persistence at high elevations. PLoS One 12:e0178066.

Sparks, D. W., and E. W. Valdez. 2003. Food habits of Nyctinomops macrotis at a maternity roost in New Mexico, as indicated by analysis of guano. The Southwestern Naturalist 48:132-135.

Taddel, V., AND V. Garutti. 1981. The Southernmost record of the free-tailed bat, Tadarida aurispinosa. Journal of Mammalogy 62:851-852.

Tavares, V. C., L. M. S. Aguiar, F. A. Perini, F. C. Falcão, and R. Gregorín. 2010. Bats of the state of Minas Gerais, southeastern Brasil. Chiroptera Neotropical 16:675-705.

Velazco, P., And S. Soları. 2003. Taxonomy of Platyrrhinus dorsalis and Platyrrhinus lineatus (Chiroptera: Phyllostomidae) in Peru. Mastozoología Neotropical 10:303- 319.

Velazco, P., R. Cadenillas, O. Centty, L. Huamaní, and H. Zamora. 2013. New records of Platalina genovensium (Chiroptera, Phyllostomidae) and Tomopeas ravus (Chiroptera, Molossidae). Mastozoología Neotropical 20:425-434.

Vidal-Martínez, V., M. Aguirre, T. Scholz, S. D. González, and E. F. Mendoza-Franco. 2002. Atlas de los helmintos parásitos de cíclidos de México. Instituto Politécnico Nacional, Ciudad de México, México.

Voss, R., AND L. Emmons. 1996. Mammalian diversity in Neotropical lowland rainforests: a preliminary assessment. Bulletin of the American Museum of Natural History 230:1-115.

Wang, H. G., R. D., Owen., C. Sánchez-Hernández, and M. D. L. Romero-Almaraz. 2003. Ecological characterization of bat species distributions in Michoacán México, using a geographic information system. Global Ecology and Biogeography 12:65-85.

Whitaker, J. O., G. F. Mccracken, and B. M. Siemers. 2009. Food habits analysis of insectivorous bats. Pp. 567-592 in Ecological and Behavioural Methods for the Study of Bats (Kunz, T. H., and S. Parsons, eds.). Second edition. Johns Hopkins University Press, Baltimore, U.S.A.

Whitaker, J. O., AND L. Castor. 2010. Identification of insect parts found in bat guano. Pp, 567-592 in Ecological and Behavioural Methods for the Study of Bats (Kunz, T. H., and S. Parsons, eds.). Second edition. Johns Hopkins University Press, Baltimore, U.S.A.

Wilson, D. 1985. New Mammal Records from Sinaloa: Nyctinomops aurispinosa and Onychomys torridus. Southwestern Association of Naturalists 30:323-324.

Associated editor: Andrés Parada

Submitted: January 8, 2020; Reviewed: May 18, 2020.

Accepted: July 11, 2020; Published on line: August 3, 2020. 


\section{Appendix I}

Records of Nyctinomops aurispinosus used in the map of the update of its distribution (Figure 3). Las letters in parenthesis indicate the records of the specimens used in the table of measurements (Table 1). Names of the corresponding collections to the abbreviations are described in Materials and Methods.

\section{Nyctinomops aurispinosus}

Perú: (A) Lima, Cerro Agustino, $12^{\circ} 06^{\prime} \mathrm{S}, 77^{\circ} 00^{\prime} \mathrm{W}$ (MUSM 235, 6051); (B) Cusco, Huajyumbe, $13^{\circ} 15^{\prime} \mathrm{S}, 70^{\circ} 30^{\prime}$ W (FMNH 68561); Lambayeque, $12 \mathrm{Km}$ al $\mathrm{N}$ de Olmos, $5^{\circ} 50^{\prime}$ S, 79 47’ W (LSUMZ 25010, 25011, 25012, 25013, 25014, 25015, 26016, 25017, 25018, 25021, 25022, 25025, 25029); Piura, Talara, $4^{\circ} 46^{\prime} \mathrm{S}, 80^{\circ} 59^{\prime} \mathrm{W}$ (AMNH 278527, CEBIOMAS 228); Arequipa, Camaná, $16^{\circ} 37^{\prime} \mathrm{S}, 72^{\circ} 43^{\prime} \mathrm{W}$; Tacna, Inclán, $17^{\circ} 49^{\prime} \mathrm{S}, 70^{\circ} 30^{\prime} \mathrm{W}$ (MUSM 48232). México: (C) Tamaulipas, Cueva de Abra, $22^{\circ} 36^{\prime} \mathrm{N}-99^{\circ} 01^{\prime} \mathrm{W}$ (TCWC 6573, 6474, IB 4838, 4839, 4841) (KU KUM 90542, 90543, 90544, 90545); (D) Colima, Pueblo Juárez, $19^{\circ} 10^{\prime} \mathrm{N}$ - 103 55'W (UAZ 7943); Colima, Las Juntas, $5 \mathrm{Km}$ al SE de Pueblo Juárez, $19^{\circ} 08^{\prime}$ N, $103^{\circ} 54^{\prime}$ W (UAZ 8553, 8554, 8555, 8556, 8583); Colima, Cuastecomatán, $19^{\circ} 7^{\prime} \mathrm{N}, 103^{\circ} 54^{\prime} \mathrm{W}$ (UAZ 8894, 8895, 8896, 8897, 8898, 8899, 8900, 8901, 8943); (E) Nayarit, $21^{\circ} 44^{\prime} \mathrm{N}$, $104^{\circ} 51^{\prime} \mathrm{W}$; San Luis Potosí, Cueva en El Salto, $22^{\circ} 09^{\prime} \mathrm{E}$, $100^{\circ} 59^{\prime}$ W (KUM 91774); (F) Michoacán, Coahuayana, $18^{\circ}$ $45^{\prime} \mathrm{N}, 103^{\circ} 38^{\prime} \mathrm{W}$ (IB 6241, 6269); Oaxaca, Juchitlán, $16^{\circ} 26^{\prime}$ $\mathrm{N}, 95^{\circ} 01^{\prime} \mathrm{W}$ (IB 4592, 1547); (G) Zacatecas, Juchipila, $21^{\circ}$ $25^{\prime} \mathrm{N}, 103^{\circ} 07^{\prime} \mathrm{W}$ (MSU 10273); (H) Sonora, rio Cuchahaqui, $26^{\circ} 52^{\prime} \mathrm{N}, 108^{\circ} 55^{\prime} \mathrm{W}$ (TTU 62969, 62970); (I) Sonora, Comanito, $25^{\circ} 10^{\prime} \mathrm{N}, 107^{\circ} 40^{\prime} \mathrm{W}$ (AMNH 244353); (J) Chihuahua, Morelos, $26^{\circ} 47^{\prime} \mathrm{N}, 107^{\circ} 41^{\prime} \mathrm{W}$, (CRD 4550). Honduras: San Marcos de Colón, $53 \mathrm{Km}$ al NE de Choluteca, 13 $27^{\circ}$ N, $86^{\circ} 55^{\prime}$ W. Colombia: (K) Bogotá, $04^{\circ} 36^{\prime} \mathrm{N}, 74^{\circ} 05^{\prime} \mathrm{W}$ (FNMH 48560). Venezuela: (L) Aragua, Estación Biológica de Rancho Grande, $10^{\circ} 21^{\prime} \mathrm{N}, 67^{\circ} 40^{\prime} \mathrm{W}$ (MBUCV 1067, EBRG 1856, 2691, 2693); Miranda, Cueva de los Carraos, $10^{\circ} 26^{\prime}$ N, 66 47’ W (OL 1065 SVE). Brazil: (M) São Paulo, São José do Rio Preto, $20^{\circ} 49^{\prime} \mathrm{N}, 49^{\circ} 23^{\prime} \mathrm{W}$ (DZSJRP 4786); São Paulo, Ribeirão Preto, $21^{\circ} 10^{\prime} \mathrm{S}, 47^{\circ} 49^{\prime} \mathrm{W}$ (MZUSP 15463); São Paulo, Estación Ecológica Caetetus, $22^{\circ} 25^{\prime} \mathrm{S}, 49^{\circ} 42^{\prime} \mathrm{W}$; São Paulo, São Paulo, $23^{\circ} 32^{\prime} \mathrm{S}, 46^{\circ} 37^{\prime}$ W; (N) Paraná, Curitiba, $25^{\circ} 25^{\prime} \mathrm{S}, 49^{\circ} 15^{\prime} \mathrm{W}$ (RA 24116); Rio Grande do Norte, $160 \mathrm{Km}$ al S de Cabo San Roque, $5^{\circ} 29^{\prime} \mathrm{S}, 35^{\circ} 26^{\prime}$ W (USNM 3726); Minas Gerais, Lavras, $21^{\circ} 07^{\prime} \mathrm{S}, 45^{\circ} 56^{\prime} \mathrm{W}$ (UFLA 4049); Minas Gerais, Uberlândia, $18^{\circ} 55^{\prime} \mathrm{S}$, 48 $16^{\circ}$ W (UFMG 6940); Distrito Federal, Brasília, $15^{\circ} 45^{\prime} \mathrm{S}, 47^{\circ} 45^{\prime} \mathrm{W}$; Piauí, Paulistana, $08^{\circ} 09^{\prime}$ S, $41^{\circ} 09^{\prime}$ W; Bolivia: (0) Santa Cruz, Haciendo Cerro Colorado, $19^{\circ} 27^{\prime} \mathrm{S}, 56^{\circ} 21^{\prime} \mathrm{W}$ (EBD_MAM 14047, 14280, 14281, 14282, 14283, 14284, 14285, 14286, 14378); La Paz, La Reserva, $15^{\circ} 44^{\prime} \mathrm{S}, 67^{\circ} 31^{\prime} \mathrm{W}$. 